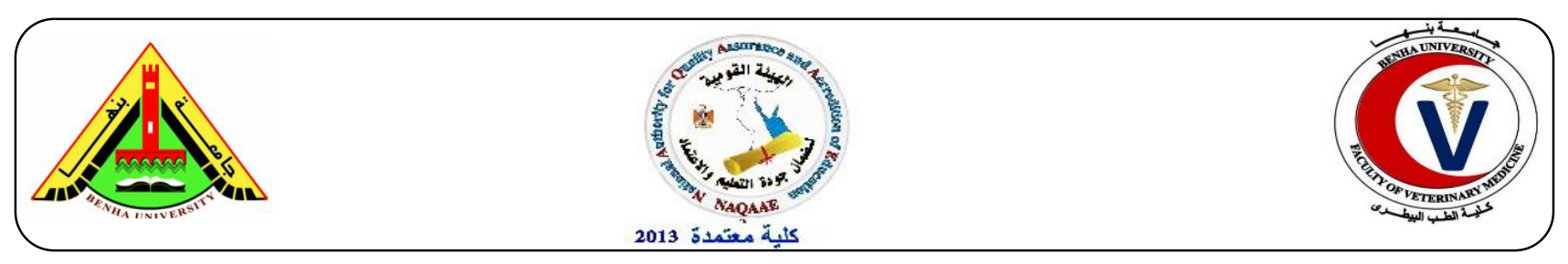

\title{
Detection of starch and hydroxyproline content in some meat products
}

\author{
Saad $^{1}$, M.S; Hassan', M.A.; Reham ${ }^{1}$, A. Amin, El- Shater' ${ }^{2}$ M.A.; Shanab ${ }^{2}$, M.S.
}

${ }^{1}$ Food Hygiene and Control Department, Faculty of Veterinary Medicine, Benha University.

${ }^{2}$ Animal Health Research. Institute, Dokki- Giza

\begin{abstract}
A B S T R A C T
This study is for detection some food additives used on manufacturing of some meat products as starch and hydroxyproline. A total of 150 random samples of locally manufactured meat products represented by beef burger, Kofta, Frankfurter, Sausage and Luncheon (30 of each) were collected from different markets in Egypt governorates. The collected samples of beef burger, kofta, frankfurter and sausage were frozen and the weight of each unit was $340 \mathrm{~g}$. while, the luncheon samples were collected as slices $(250 \mathrm{gm})$. Each sample was kept in a separate plastic bag and preserved in an ice box then transferred to the laboratory without undue delay. The collected samples were subjected to chemical examination for evaluation of starch content and Hydroxyproline content (\%). The mean values of starch content (\%) in Beef burger, Kofta, Frankfurter, Sausage and Luncheon were $4.47 \pm 0.19,4.81 \pm 0.25,4.03 \pm 0.17,5.10 \pm 0.32$ and $5.54 \pm 0.36$, respectively. Moreover the mean values of Hydroxyproline (\%) in Beef burger, Kofta, Frankfurter, Sausage and Luncheon were $0.387 \pm 0.029$, $0.412 \pm 0.036,0.393 \pm 0.032,0.478 \pm 0.042$ and $0.440 \pm 0.039$, respectively. The current study revealed that many of meat products under examination were not acceptable to the limits standardized by EOS (2005).
\end{abstract}

Keywords: Starch, hydroxyproline, beef burger, kofta, sausage.

\section{INTRODUCTION}

During the last decade, the demand for meat products has increased in food markets, so, the quality of raw material (meat) as well as additives and final products are very important for public health (Pearson and Gillette, 1996). Today, more than 2500 different additives are internationally added to food to produce desired flavor and taste (Mega and Tu, 1995). The quality and price of the finished products will largely control the selection of used meat, thus the chemical composition of each product is greatly varied from one product to another and it contains different kinds of tissues and sometimes a meat mixture of various organs (Lawrie, 1998).

Using of food additives has become more prominent in recent years as Consumers need high quality, natural, nutritious, fresh

Appearance and convenient meat products with natural flavor and taste and an extended shelf life (Aymerich et. al. 2008).

Starch has traditionally been used in meat products to improve quality and occasionally to extend the more expensive meat fraction of 
various products. The effect of starch addition is based on the ability of the starch to gelatinize when heated in a water-containing medium, thereby binding relatively large amounts of water.

The most commonly used starches are corn starch, potato starch, wheat flour and certain types of so called modified starches .The function of starches in meat products during heating and gelatinization is to absorb the water which is liberated because of heat shrinkage of proteins (Jakobsen, 1990).

Acceptance of these food additives has been hindered by problems involving assessment of the net benefits of their use (Denner, 1990).

The addition of low value meat cuts is generally considered to be the most frequent adulteration of meat -based products, such as sausage, hamburger. Hydroxyproline, a nonessential amino acid constituents of proteins, is mainly found in connective and bone tissue and forms up to $10 \%$ of collagen molecules. So, Hydroxyproline is considered as a suitable marker for identifying the quality of raw material used for meat, the amino acid 4hydroxyproline (Stanley, 1983 and Messia and Marconi, 2011).

Meat consists of connective tissue proteins, which decrease tenderness of meat. Collagen is the most common protein found in connective tissue.

For the manufacture of processed-meat products, meat with high levels of collagen can result in detrimental effects on endproduct quality, such as gelatin formation, grainy and brittle texture, which are all undesirable. The nutritive value of the product decreases, as connective tissue is deficient in essential amino acids (Lyasoglu et. al. 2003)

Therefore, the current study was planned out to determine the starch and hydroxyproline contents in some locally manufactured meat products (Beef burger, Kofta, Frankfurter, Sausage and Luncheon).

\section{Materials and methods}

A total of 150 random samples of locally manufactured meat products represented by beef burger, kofta, frankfurter, sausage and luncheon (30 of each) were collected from different markets in Egypt governorates. The collected samples of beef burger, kofta, frankfurter and sausage were frozen and the weight of each unit was $340 \mathrm{~g}$. while, the luncheon samples were collected as slices (250g).

Each sample was kept in a separate plastic bag and preserved in an ice box then transferred to the laboratory without undue delay. The collected samples were subjected to chemical examination for evaluation of Starch and Hydroxyproline contents.

2.1. Determination of starch (AOAC, 2005):

\subsubsection{Qualitative determination:}

From the examined sample, $5 \mathrm{~g}$ were treated with boiled water. Then left for cooling and the superior liquid portion is treated with lugol solution (obtained by solving $0.5 \mathrm{~g}$ iodine and $1.5 \mathrm{~g}$ Poiassium iodide in water and then completed with water till $25 \mathrm{ml}$ volume). In case that a blue color appears, the probe is considered positive. If the color is very strong, this may be a clue that there is a high starch content or other cereal products supplement (with a fraud intention). To verify this fact, from the obtained sediment a small part is taken and a microscopic examination is made in order to determine the type of added starch.

2.1.2. Quantitative determination of starch:

The principle of this determination lies on the starch hydrolyze till simple reducing sugar (glucose) is obtained. This was determined by using Bertrand method.

At a technical balance $20 \mathrm{~g}$ of the analyze probe were taken and $100 \mathrm{ml}$ of $\mathrm{KOH}$ alcoholic solution (obtained by solving $80 \mathrm{~g}$ of $\mathrm{KOH}$ to $1000 \mathrm{ml}$ ethylic alcohol (97-98\%) was added. The alcoholic solution would be firstly heated to $70-80{ }^{\circ} \mathrm{C}$. After mixing with the $\mathrm{KOH}$ 
alcoholic solution, the probe was refluxed for 30 - 40 minutes, till dissolution. It was left for cooling and then it was quantitatively passed in a big centrifuge vial and then centrifuged 5 minutes at $2500 \mathrm{rpm}$. It was left for decanting and the superior liquid portion was discarded. The precipitate and the centrifuge vial were washed for 2 or 3 times with $15-20 \mathrm{ml}$ ethyle alcohol which was eliminated by centrifugation or filtration. The insoluble residue that remained by centrifugation was quantitatively reintroduced in the initial flask along $100 \mathrm{ml}$ of hydrochloric acid $1 \mathrm{~N}$. An ascending refrigerant was attached and the mix was cooled on the water bath for 2.5 hours, to ensure starch hydrolyze. After this, the flask was cooled at the water tap.

The hydrolyzed product was neutralized with $\mathrm{NaOH}$ in the presence of bromthymol blue indicator till green color was reached $(\mathrm{pH}=$ 6.3). The mix is quantitatively passed in a 250 $\mathrm{ml}$ flask and $3 \mathrm{~mL}$ of Potassium iron cyanide solution with $3 \mathrm{ml}$ of Zinc acetate solution are added. In this way, protein removal was assured. In order to facilitate this operation we must agitate after each supplement. The mix was left 30 minutes to rest and then was completed with water till $250 \mathrm{ml}$ volume was reached. Then a filtration is made through a funnel and a filter with low porosity. From the obtained solution, one can determine the reducing sugar (glucose) by spectrophotometer (Unico SQ 2802, USA).

2.2. Determination of Hydroxyproline and collagen (AOAC, 2005):

Hydroxyproline content was determined according to the method recommended by Kolar (1990). Briefly, $4 \mathrm{~g}$ of the sample was mixed with $30 \mathrm{ml}$ of sulphuric acid and hydrolysed in Erlenmeyer flasks in an air convection oven at $105^{\circ} \mathrm{C}$ for 16 hours.

Hydrolysed samples were filtered and after that $2 \mathrm{ml}$ of the hydrolysed diluted sample was mixed with $1 \mathrm{ml}$ of oxidative solution chloramine $\mathrm{T}(1.41 \%)$ prepared directly before use in an aqueous buffer solution containing 15 $\mathrm{g}$ of Sodium hydroxide, $90 \mathrm{~g}$ of Sodium acetate trihydrate, $30 \mathrm{~g}$ of citric acid monohydrate, and $290 \mathrm{ml}$ of 1-propanol per litre. The reaction tubes were shaken and then incubated at room temperature for 20 minutes.

After that $1 \mathrm{ml}$ of reactive color $(10 \mathrm{~g}$ of dimethylamine benzaldehyde with $35 \mathrm{ml}$ of $60 \%$ sulphuric acid and $65 \mathrm{ml}$ of 2-propanol) was added and the mixture was incubated at $60^{\circ} \mathrm{C}$ for 15 minutes. After incubation, absorbance was measured at $558 \mathrm{~nm}$ using spectrophotometer. The stock solution of the standard to create a standard curve was 0.1 , $0.5,1.0,1.5$, and $2.0 \mathrm{mg} / \mathrm{ml}$. All standard solutions were prepared directly before use. Mean connective tissue (collagen) \% was calculated based on hydroxyl proline $\%$ in the examined samples.

\section{RESULTS}

The results recorded in the table (1) revealed that the mean values of starch content $(\%)$ in beef burger, kofta, frankfurter, sausage and luncheon were $4.47 \pm 0.19, \quad 4.81 \pm 0.25$, $4.03 \pm 0.17, \quad 5.10 \pm 0.32$ and $5.54 \pm 0.36$, respectively .with minimum values of $3.3,3.8$, $3.1,4.0$ and 4.3 and maximum values of 5.4, $5.7,5.1,6.1$ and 6.6 respectively for the above mentioned meat products samples.

Table (2) revealed that the most acceptable product was frankfurter $(93.3 \%)$ while the lowest acceptable one was luncheon (53.3\%) according to (EOS 2005) whom intended that carbohydrates percent in meat products must not be more than $10 \%$.

The results recorded in table (3) revealed that the mean values of hydroxyproline in beef burger, Kofta, Frankfurter, Sausage and Luncheon were $0.387 \pm 0.029,0.412 \pm 0.036$, $0.393 \pm 0.032,0.478 \pm 0.042$ and $0.440 \pm 0.039$ respectively .with minimum values of 0.377 , $0.389,0.363,0.402$ and 0.397 and maximum values of $0.421,0.433,0.414,0.549$ and 0.521 
respectively for the above mentioned meat product samples.
Mean scores for connective tissue contents (\%) were $1.084,1.172,0.985,1.681$ and 1.409 , respectively for the above mentioned meat products.

Table 1: Statistical analysis of starch content $(\%)$ in the examined samples of locally manufactured meat products $(n=30)$.

\begin{tabular}{lccccc}
\hline \multirow{2}{*}{ Meat products } & \multicolumn{2}{l}{ +ve samples } & & Max & Mean \pm S.E* \\
\hline Beef burger & No & $\%$ & Min & 5.4 & $4.47 \pm 0.19$ \\
Kofta & 16 & 53.3 & 3.3 & 5.7 & $4.81 \pm 0.25$ \\
Frankfurter & 18 & 60 & 3.8 & 5.1 & $4.03 \pm 0.17$ \\
Sausage & 12 & 40 & 3.1 & 5.1 & $5.10 \pm 0.32$ \\
Luncheon & 19 & 63.3 & 4.0 & 6.1 & $5.54 \pm 0.36$ \\
& 25 & 83.3 & 4.3 & 6.6 & \\
\hline
\end{tabular}

Table 2: Acceptability of the examined locally manufactured meat products according to their contents of starch $(n=30)$.

\begin{tabular}{lllllc}
\hline \multirow{2}{*}{ Meat Products } & Starch $(\%)$ & \multicolumn{2}{c}{ Accepted samples } & \multicolumn{2}{c}{ Unaccepted samples } \\
& & No. & $\%$ & No. & $\%$ \\
\hline Beef burger & $<5$ & 30 & 90 & 3 & 10 \\
Kofta & $<5$ & 30 & 83.3 & 5 & 16.7 \\
Frankfurter & $<5$ & 30 & 93.3 & 2 & 6.7 \\
Sausage & $<5$ & 30 & 66.6 & 10 & 33.3 \\
Luncheon & $<5$ & 30 & 53.3 & 14 & 46.7 \\
\hline
\end{tabular}

S.E $E^{*}=$ standard error of mean

*Egyptian Organization for Standardization "EOS" (2005).

No 1688-2005 for beef burge

No 3492-2005 for frankfurter

No 1114-2005 for luncheon
No 1973-2005 for kofta

No 1972-2005 for sausage 
Table 3: Statistical analysis of hydroxyl proline and connective tissue contents "C.T" (\%) in the examined samples of locally manufactured meat products $(n=30)$.

\begin{tabular}{lcccc}
\hline & \multicolumn{2}{l}{ Hydroxy proline \% } & \\
Meat products & Min & Max & Mean \pm S.E & Mean C.T ${ }^{*} \%$ \\
\hline Beef burger & 0.377 & 0.421 & $0.387 \pm 0.029$ & 1.084 \\
Kofta & 0.389 & 0.433 & $0.412 \pm 0.036$ & 1.172 \\
Frankfurter & 0.363 & 0.414 & $0.393 \pm 0.032$ & 0.985 \\
Sausage & 0.402 & 0.549 & $0.478 \pm 0.042$ & 1.681 \\
Luncheon & 0.397 & 0.521 & $0.440 \pm 0.039$ & 1.409 \\
\end{tabular}

Mean C.T ${ }^{*}=$ Mean connective tissue $\%$ was calculated based on hydroxyl proline $\%$ in the examined samples.

\section{DISCUSSION}

The Food Additives classified into two groups of food additives from FDA's testing and approval process. One is the list of substances known as "generally recognized as safe" (GRAS). This group includes a variety of substances, from commonly used flavorings and spices to phosphates and carrageenan. These substances are considered harmless under prescribed conditions of use. Past extensive use of these substances has produced no known harmful effects (Food safety and inspection service, 2014).

Some meat products producers may add starch as a source of carbohydrate in meat products which also reduce formulation cost, improve flavor and to increase water binding capacity.

The results recorded in the table (2) revealed that the highest acceptable product for its starch content is Frankfurter $(93.33 \%)$ while the lowest acceptable product is Luncheon (53.33\%) according to the (EOS 2005).

These results are similar to those obtained by (EL-Sayed,1995) who said that the mean values of starch \% in frankfurter and luncheon were $3.9 \pm 0.08$ and $5.17 \pm 0.35$, respectively while lower results were recorded by (ElZahaby,2013) for luncheon and frankfurter .

Food starches improve texture and reduce purge accumulation in low fat bologna, it has also been reported that potato starch was very beneficial in improving the texture of low- fat frankfurter (Claus and Hunt, 1991).

There is a high proportion of Hydroxyproline amino acid "nonessential" in collagen and elastin, while tryptophane "essential amino acid" is virtually absent. Hydroxyproline content of muscle, is therefore, frequently used as a measure of its connective tissue. The ratio of tryptophane to Hydroxyproline used as indicator for the quality of meat products. 
A high proportion of hydroxyproline amino acid "non-essential" in collagen and elastin while tryptophan "essential amino acid" is virtually absent. The hydroxyproline content of muscle is therefore, frequently used as a measure of its connective tissue. The ratio of tryptophan to hydroxyproline used as indicator for the meat quality of meat products (Ranken 2000).

Moreover the results obtained on table(3) were nearly similar to those obtained by El-Khawas (1996) and El-Sayed (2006) for luncheon, burger and frankfurter while higher results were obtained by (Ayman , 2011 and MoawadShimaa, 2012) for beef burger, luncheon and sausages.

The connective tissue proteins of low biological values as they are deficient in essential amino acids tryptophan "Collagen",while elastin and Reticulin are deficient in cysteine, Tyrosine and Tryptophan.

\section{Conclusion}

It is concluded from this study that some of the examined samples showed unacceptable levels for starch content described by (EOS 2005), while the same products showed high acceptable level for its contents of the hydroxyproline and connective tissue.

\section{REFERENCES}

Association of Official Analytical Chemists "AOAC" (2005): Official methods of analysis. 14 ${ }^{\text {th }}$ Ed., W. Horwitz .w, (Editor), Academic Press, Washington, D.C., USA.

Ayman, M.Abd El-Sadek (2011): Studies on adulteration of locally manufactured meat products with special references to animal species identification.
Ph.D.V.Sc. Thesis, Fac. of Vet. Med., Benha Univ.

Aymerich, T. Picouet, P.A. and Monfort J.M. (2008): Decontamination technologies for meat products. Meat Science, 78(12): 114-129.

Claus, J. R. and Hunt, M .C. (1991): Low -fat, high added bologna formulated with texture-modifying ingredients .Journal of Food Science, 56:643-647.

Denner, W.H.B. (1990): Food additives, recommendations for harmonization and control. Review, Food control, J., 42: $150-162$.

El-Khawas, K. M. S. (1996): Public health aspects of canned meat. M.V.Sc. Thesis, Fac. Vet. Med. Zagazig Univ.

EL-Sayed, M. E. (1995): Microbial and chemical evalution of some heat treated meat products Ph. D. Fac. of Vet. Med., Alex. Univ.

El-Sayed, A.E. (2006). Organoleptic and chemical evaluation of some locally manufactured beef burger. M.V.Sc. Thesis, (Meat Hygiene). Fac. Vet. Med., Benha Univ.

EL-Zahaby, D. I. (2013): Chemical evaluation of some food additives in meat products. Ph. D. V.Sc. Thesis, (Meat Hygiene). Fac. Vet. Med., Benha Univ.

EOS (2005): Egyptian Standard Specification or Egyptian Organization for Standardization and Quality Control for meat products.

Food safety and inspection service (2014): Additives in Meat and Poultry Products, United States Department of Agriculture, Food Safety and Inspection Service, August 2014. 
Jakobsen, B. (1990): Hand book for the meat processing industry. Copenhagen pectin A/S Denmark. Hercules Incorporated Wilmington Delaw are USA.

Lawrie, A.R. (1998):Lawri's meat science. $6^{\text {th }}$ Ed.Wood head publishing Ltd .USA.

Lyasoglu, H., Nilüfer, D. and Boyacioglu, D. (2003). I 14- "Hydroxyproline determination methods in meat products" IFT Annual Meeting \& Food Expo., Chicago, IL, USA.

Mega, J. A. and Tu, A.T. (1995): Food additives toxicology Colorado State Univ.fort Collins, USA, PP.542.

Messia, M.C. and Marconi, E. (2011).Innovative and Rapid Procedure for 4-Hydroxyproline Determination in Meat.

Moawad-Shaimaa, M. N. (2012): Chemical indices as quality measures in meat products. Ph. D. Sc. Meat hygiene thesis, Fac. of Vet. Med., Moshtohor, Benha branch.

Pearson, A.M. and Gillette, T.A. (1996). Processed meats. 3 rd Ed. New York Albany, Bonn, Boston, London

Stanley, D.W. (1983). Relation of structure to physical properties of animal materials. In M. Peleg \& E.B. Bagley (Eds.), Physical properties of foods. Westport, Connecticut: Avi Publish. Comp., Inc. 